\title{
Mexican pharmacies: benefits and risks for border residents in the United States of America and Mexico
}

\author{
Núria Homedes ${ }^{1}$ and Antonio Ugalde ${ }^{2}$
}

Suggested citation Homedes N, Ugalde A. Mexican pharmacies: benefits and risks for border residents in the United States of America and Mexico. Rev Panam Salud Publica. 2013;33(3):196-204.

ABSTRACT Objective. To determine the benefits and risks of using Mexican pharmacies by better understanding the sociodemographics and medication needs of pharmacy clients in Ciudad Juárez; and to ascertain the role and expertise of pharmacy clerks and their impact on medication use.

Methods. Cross-sectional study of a convenience sample of 32 pharmacies in Ciudad Juárez conducted in August 2007-January 2008. Medical professionals interviewed 230 pharmacy clients and 25 pharmacy owners and clerks, and observed 152 clerk-client interactions. The cost of the most frequently-purchased medications was compared with pricing at pharmacies in El Paso, Texas, United States.

Results. Of the 311 medications purchased, the most frequent were: antibiotics (54), analgesics (49), fixed drug combinations (29), and blood pressure medications (26). Only $38 \%$ were purchased with a prescription; $62 \%$ of the prescription drugs bought without a prescription were self-prescribed. Many products purchased were of limited therapeutic value, and others could be harmful when used inappropriately. Pharmacy clerks were poorly trained and did not offer appropriate information on drug use; contraindications were never discussed. Contrary to popular perception, some generic drugs were cheaper in the United States than in Mexico. Conflicts of interest were identified that could be leading to over-medication.

Conclusions. While the risks are evident, some uninsured, chronically-ill United States residents may benefit from access to medications previously recommended by a physician, without obtaining a new prescription. The authors suggest five steps for reducing the risks and improving pharmaceutical utilization in the border area.

Key words Community pharmacy services; education, pharmacy; prescription drugs; border areas; Mexico; United States.

The high cost of pharmaceuticals in the United States of America has many consumers turning to neighboring countries or the Internet for their medications. The practice of purchasing medication north

\footnotetext{
University of Texas, School of Public Health, Houston, Texas, United States of America. Send correspondence to Núria Homedes, email: nhomedes@utep.edu

2 University of Texas, Department of Sociology, Austin, Texas, United States of America.
}

of the border, from Canada, was a topic of public debate, with federal and state legislators repeatedly pursuing legalization $(1,2)$. The Pharmaceutical Market Access and Drug Safety Act of 2007 (3) legalized the purchase of medicines in approved Canadian pharmacies if the United States Food and Drug Administration (FDA) guaranteed their quality.

Likewise, United States residents living near the country's southern border frequently obtain medicine at Mexican pharmacies, but legalization of the practice has not captured the attention of legislators. A possible explanation for this is the uncertainty regarding what impact it would have on the health of United States border residents. Some researchers (4-6) discourage the use of Mexican pharmacies based on the absence of a robust and reliable quality assurance program in the country. In 2004, the FDA 
found that some Mexican border pharmacies were selling simvastatin (Zocor ${ }^{\circledR}$ ) and carisoprolol with lower quantities of the active ingredients than stated on the labels; a similar observation was made in 2005 with regard to Evista, ${ }^{\circledR}$ Lipitor, ${ }^{\circledR}$ and Viagra ${ }^{\circledR}(7,8)$. However, other studies $(9,10)$ have shown that Mexican medications comply with the standards of the United States Pharmacopeia.

The United States has 24 counties that border Mexico comprising a population of about 6.5 million individuals, mostly young $(29 \%<18$ years of age) and Hispanic (>50\%). The area has high poverty rates, low levels of education, a high proportion of uninsured individuals (mean: 26\%; range: $20 \%-38 \%$ ), and a chronic shortage of health professionals (11). Within this area are the two cities selected for the present study: Ciudad Juárez, Mexico, and El Paso, Texaseconomically and socially intertwined, essentially constituting one metropolitan area with 2 million inhabitants, yet separated by an international border.

Several studies of United States border cities show that $20 \%-30 \%$ of the residents receive health care services in Mexico (12-16), and an even higher percentage use its pharmacies. Buying medication in Mexico is convenient because regulators only enforce the prescription requirement for controlled substances ${ }^{3}$ and antibiotics, the latter only since August 2010. Socioeconomics also come into play: the proportion of United States residents using Mexican pharmacies is higher among low-income groups (15-20). A study of 80 low-income migrant households in El Paso County, Texas, found that $40 \%$ of those who had been sick during the 12 months prior to the interview selfmedicated, while an additional 10\% used Mexican pharmacies and a full $85 \%$ had obtained medications from Mexico (21). In Ciudad Juárez, pharmacy chains are rapidly expanding. Individually-owned pharmacies, referred to as traditional pharmacies, are dispersed throughout the city and primarily serve the local population. They tend to be small and their prices are higher than those of pharmacy chains. Unable to compete with the chains, traditional pharmacies are closing, or staying afloat by reducing their pharmaceutical stocks and selling other products, such as food, flowers, and/ Medications such as analgesic opioids, benzodiaz-
epines, codeine, and barbiturates. or furniture, and offering services, such as photocopying (22). Pharmacy chains tend to be located in shopping centers and within close proximity of the international bridges (1-3 blocks away). There are no Mexican regulations dictating who can own a pharmacy, but physicians are not permitted to practice on the premises (23). Nevertheless, most pharmacies have arrangements with physicians in nearby "clinics," some adjacent to the pharmacy, but with a separate entrance. These walkin clinics offer consultations at affordable prices $(22,24)$. Mexican pharmacies require a current doctor's prescription only for controlled substances and antibiotics (as of August 2010); all other prescriptions can be reused for as long as the client keeps them (23). Thus, simply having a prescription does not ensure that the client is currently under medical supervision. Moreover, a controversial regulation to discourage self-medication limits the amount of information available on the pamphlet insert that accompanies most prescription medications (23); therefore, patients have to rely on the information written in the prescription, or on the verbal recommendation of clerks.

Regarding pharmacy clerks, Mexico does not impose any educational prerequisites beyond completion of secondary education for the position, though clerks can be quite influential. Clerks work largely unsupervised since Mexican law requires that a chemist-pharmacobiologist (QFBs) be present only for a few hours per week in pharmacies where controlled substances are sold. QFBs are primarily trained to work for industries and chemical or clinical labs; only recently have a few universities started training hospital and community pharmacists.

The study objectives were: 1) to determine the sociodemographic characteristics and health and pharmaceutical needs of pharmacy clients in Ciudad Juárez; and 2) to establish the role and capability of the pharmacy clerks to contribute to the appropriate use of pharmaceuticals in the area.

\section{MATERIALS AND METHODS}

This was a descriptive, cross-sectional study of pharmacies, pharmacy clerks, and pharmacy clients in Ciudad Juárez, Mexico, conducted in August 2007-January 2008. A convenience sample of pharmacies was drawn from the 2007 municipal records of Ciudad Juárez, which listed
308 private pharmacies; of these, 208 were individually-owned, and the remainder, pharmacy chains. After plotting these on a city map, 32 pharmacies were selected, giving preference to those frequented by border residents. Of these, 23 were pharmacy chains and 9 were traditional. Some were accessible to pedestrians crossing from El Paso; others were in or near major shopping centers frequented by United States residents; and a few were located in the interior of Ciudad Juárez. All of the traditional pharmacy owners agreed to participate. Access to pharmacy chains had to be obtained from the company headquarters, all but one of which was located in other cities. This was a cumbersome process that, in some cases, took several months. All but two agreed to participate.

The study had three components:

I. A survey of 230 pharmacy clients, half of which were United States residents. The interviewers approached the clients as they left the pharmacy, explained the study and, if eligible, obtained their consent and applied the questionnaire. Eligible clients had to have purchased medications and be at least 18 years of age. After asking to see their purchases, the interviewer took note of product names; amounts purchased; whether or not the consumer had a prescription, and if not, who had recommended the medication; the sociodemographic characteristics of the client; the sociodemographic characteristics and health problems of the end-user of the products; the reason(s) why a United States resident was purchasing medicine in Mexico; and their experience with United States customs. All, except one, of the interviews were conducted in Spanish; 82\% took place in the pharmacy and the remainder, on the sidewalk immediately outside.

II. To ascertain the role and influence of pharmacy clerks on the selection and purchase of medication, study observers monitored 152 interactions between clerks and clients from a discrete position near the counter using a guide specifically prepared for this purpose.

III. To gather information on each pharmacy's history, services offered, sociodemographics, training of its clerks, and its relationship with the 
pharmaceutical industry and wholesalers, interviews were conducted with the pharmacy owner or highestranking clerk. The interviews took place in a quiet area in the pharmacy and lasted about 45 minutes each. For budgetary reasons, only 25 of the 32 pharmacies were included (16 chain pharmacies and 9 traditional).

All of the questionnaires, including pre-coded and open-ended questions, and the observer's guide were pilottested in three pharmacies.

In August-November 2007, two bilingual nurses from the Mexican Institute of Social Security (IMSS) carried out components I and II of the study, conducting client interviews and observing clerk-client interactions 7 days a week at varying times of day (8 a.m.-8 p.m.).

In December 2007-January 2008, the Mexican physician who had supervised the fieldwork completed component III by interviewing 25 pharmacy owners/clerks. To verify any price advantage of Mexican pharmacies over United States pharmacies, the researchers visited several on both sides of the border, gathering pricing information on 15 of the medications most frequently purchased by the study respondents.

This quantitative information is supplemented by fieldwork observations and knowledge acquired during the years that the authors have resided along and conducted research on the United States-Mexico border.

One of the principal researchers $(\mathrm{NH})$ and the Mexican physician coded all open questions. All data were entered into a Microsoft Excel ${ }^{\mathrm{TM}}$ (Microsoft Corp., Redmond, Washington, United States) spreadsheet and were analyzed using IBM SPSS Statistics software, version 18 (SPSS Inc., an IBM company, Chicago, Illinois, United States).

The study and consent methods were approved by the Institutional Review Boards of the University of Texas, Health Science Center in Houston, and of the National Institute of Public Health, Cuernavaca, Mexico.

\section{RESULTS}

\section{Characteristics of clients and pharmacies}

Table 1 shows that among clients of the 32 pharmacies studied in Ciudad

TABLE 1. Sociodemographics and health condition of pharmacy clients at 32 pharmacies in Ciudad Juárez, Mexico, and of the medication's intended recipient (end-user), by country of residence, August-November 2007

\begin{tabular}{|c|c|c|c|c|}
\hline \multirow[b]{3}{*}{ Characteristic } & \multicolumn{4}{|c|}{ Country of residence } \\
\hline & \multicolumn{2}{|c|}{ Mexico } & \multicolumn{2}{|c|}{ United States } \\
\hline & No. & $\%$ & No. & $\%$ \\
\hline \multicolumn{5}{|l|}{ Clients of pharmacies in Ciudad Juárez } \\
\hline Total number of pharmacy clients & 121 & 100 & 109 & 100 \\
\hline \multicolumn{5}{|l|}{ Country of employment } \\
\hline Mexico & 86 & 71 & 10 & 9 \\
\hline United States & 24 & 20 & 81 & 74 \\
\hline Retired & 11 & 9 & 18 & 17 \\
\hline \multicolumn{5}{|l|}{ Client intends to import medicine into the United States } \\
\hline Yes & 13 & 11 & 104 & 95 \\
\hline No & 109 & 89 & 5 & 5 \\
\hline Average number of medications purchased, (range) & \multicolumn{2}{|c|}{$1.3(1-3)$} & \multicolumn{2}{|c|}{$1.4(1-5)$} \\
\hline Total medications purchased & 157 & 100 & 154 & 100 \\
\hline \multicolumn{5}{|l|}{ Sociodemographics of end-user } \\
\hline \multicolumn{5}{|l|}{ Age of end-user, in years } \\
\hline$<30$ & 68 & 43 & 35 & 23 \\
\hline $30-49$ & 60 & 38 & 75 & 49 \\
\hline$\geq 50$ & 29 & 19 & 43 & 28 \\
\hline \multicolumn{5}{|l|}{ Gender of end-user } \\
\hline Male & 82 & 52 & 84 & 55 \\
\hline Female & 75 & 48 & 70 & 45 \\
\hline \multicolumn{5}{|l|}{ Insurance coverage of end-user ${ }^{a}$} \\
\hline No insurance & 58 & 37 & 89 & 58 \\
\hline Mexican Social Security & 69 & 44 & 17 & 11 \\
\hline Public United States insurance & 13 & 8 & 16 & 10 \\
\hline Private United States insurance & 5 & 3 & 12 & 8 \\
\hline No information & 12 & 8 & 20 & 13 \\
\hline \multicolumn{5}{|l|}{ Health problem/symptoms of end-user } \\
\hline Total symptoms mentioned & 139 & 100 & 141 & 100 \\
\hline Musculoskeletal and joint pain & 21 & 15 & 12 & 9 \\
\hline Gastrointestinal problem & 21 & 15 & 20 & 14 \\
\hline Upper Respiratory problem & 18 & 13 & 21 & 15 \\
\hline Infections & 15 & 11 & 22 & 16 \\
\hline Gynecological problem & 11 & 8 & 13 & 9 \\
\hline High blood pressure & 8 & 6 & 11 & 8 \\
\hline Diabetes & 4 & 3 & 7 & 5 \\
\hline Fatigue & 8 & 6 & 3 & 2 \\
\hline Thyroid problem & 1 & 1 & 8 & 6 \\
\hline Other problems and symptoms & 32 & 23 & 24 & 17 \\
\hline Symptoms diagnosed by a physician & 89 & 57 & 65 & 42 \\
\hline
\end{tabular}

a At the time of the study very few residents of Ciudad Juárez had enrolled in Seguro Popular, a Mexican insurance program for the underprivileged that offers free medications.

Juárez, 20\% were Mexican residents working in the United States, a number of which purchased medication for a United States resident. Similarly, 9\% were United States residents working in Mexico, of which 5\% purchased medication for a Mexican resident.

Only $38 \%$ of the medications were purchased with a prescription, and $90 \%$ of the prescriptions had been written by Mexican physicians, including $68 \%$ of those prescriptions presented by United States residents.

An important person within the association of traditional pharmacies men- tioned that if patients lack prescriptions some pharmacies would sell them along with the medicine to facilitate their entry into the United States (13 May 2007). One pharmacy chain advertised the presence of a nearby physician who, for a small fee (about US\$ 2.00), would diagnose an individual and write a prescription.

According to the responses to a multiple-response question United States residents had bought their medicine in Ciudad Juárez because of cost $(81 \%)$, perceived quality $(37 \%)$, and because a prescription was not required (37\%). 
TABLE 2. Price of medications most frequently purchased from select pharmacies in Ciudad Juárez, Mexico, compared to prices in EI Paso, United States, in US\$, January 2008

\begin{tabular}{|c|c|c|c|c|}
\hline \multirow{2}{*}{$\begin{array}{c}\text { Medication } \\
\text { (quantity in tablets } \\
\text { unless otherwise specified) }\end{array}$} & \multicolumn{2}{|l|}{ Lowest price } & \multicolumn{2}{|l|}{ Highest price } \\
\hline & Location & Price & Location & Price \\
\hline \multicolumn{5}{|l|}{ Antibiotics } \\
\hline Amoxicillin 500 mg (30) & Mexican pharmacy chain & 3.39 & Mexican pharmacy chain & 17.28 \\
\hline Cephalexin 500 mg (30) & $\begin{array}{l}\text { Walmart }{ }^{\mathrm{b}} \text { and other United States } \\
\text { pharmacies }\end{array}$ & 4.00 & Mexican pharmacy ${ }^{c}$ & 46.80 \\
\hline \multicolumn{5}{|l|}{ Pain } \\
\hline Acetaminophen 500 mg (200) & Walmart & 4.00 & Mexican pharmacy chain & 49.80 \\
\hline Diclofenac (see varying quantities) & Walmart (60 tablets, 75 mg) & 4.00 & Mexican pharmacy (30 tablets, $100 \mathrm{mg}$ ) & 18.72 \\
\hline Ibuprofen 200 mg (200) & Walmart & 4.00 & Mexican pharmacy & 78.00 \\
\hline Ibuprofen 400 mg (90) & Walmart & 4.00 & Mexican pharmacy chain & 80.73 \\
\hline lbuprofen 800 mg (60) & Walmart & 4.00 & Mexican pharmacy chain & 53.82 \\
\hline \multicolumn{5}{|l|}{ Diabetes } \\
\hline Glyburide 5 mg (60) & Mexican pharmacy chain & 2.16 & Mexican pharmacy chain & 4.56 \\
\hline Insulin NPH (10 ml) & United States FQHC ${ }^{d}$ pharmacy & 10.06 & United States pharmacy & 46.49 \\
\hline \multicolumn{5}{|l|}{ Blood pressure } \\
\hline Propranolol 40 mg & United States pharmacy (180 pills) & 12.00 & Mexican pharmacy chain (30 pills) & 22.20 \\
\hline \multicolumn{5}{|l|}{ Other } \\
\hline Omeprazole 20 mg (30) & Mexican pharmacy chain & 3.99 & Mexican pharmacy & 19.32 \\
\hline Sildenafil 50 mg/Viagra ${ }^{\circledR}(30)$ & United States FQHC pharmacy & 10.06 & Walmart & 433.84 \\
\hline Multivitamin/iron (100) & United States FQHC pharmacy & 7.50 & Mexican pharmacy chain & 44.00 \\
\hline
\end{tabular}

\section{Cost comparison}

The price of the 15 most frequently purchased medicines, all of which were out of patent, had wide variability among the pharmacies in Ciudad Juárez, and when compared to those of El Paso. Contrary to client perception, at the time of this study, Walmart (Wal-Mart Stores, Inc., Bentonville, Arizona, United States) and federally qualified health center (FQHC) pharmacies offered some of the medications at prices lower than those found at pharmacies in Ciudad Juárez (Table 2).

\section{Medications purchased in Ciudad Juárez}

Table 3 presents the type of medications purchased with and without a prescription, according to the end-user's country of residence.

Some fixed drug combinations are considered irrational; for example, combinations of several nonsteroidal anti-inflammatory drugs (NSAIDs), NSAIDs and muscle relaxants, NSAIDs and antihistaminics, and antidiarrheals with penicillin. Other products, such as antidiarrheals and cough medicines, are of little thera- peutic value, and could represent a waste of resources. More troublesome is the fact that of the 192 products sold without a prescription, 120 were prescriptiononly drugs. Thus, none of the patients who obtained analgesic opioids or oral contraceptives had a prescription; and a high proportion of antibiotics, blood pressure medications, thyroid medicine, and corticosteroids were sold without prescriptions. None of the United States residents who obtained thyroid medicine and/or testosterone had a prescription; and only $10 \%, 20 \%, 25 \%$, and $50 \%$ of those who purchased blood pressure medication, corticosteroids, antibiotics, and antiepileptics/antidepressants/ansiolytics, respectively, had one.

Two-thirds of the 120 prescription-only medications obtained without a prescription were for United States residents, and of those, $70 \%$ were self-prescribed and $10 \%$ were recommended by a physician, though the absence of a prescription suggests that the patient was not currently under medical supervision. The remaining $20 \%$ were either recommended by a pharmacy clerk $(10 \%)$ or others $(9 \%)$ including traditional healers. Mexican residents were less prone to self-prescribe $(46 \%)$ with prescription-only medicines, and tended to rely more on the advice of physicians $(24 \%)$ and pharmacy clerks $(20 \%)$.

Most clients bought the amount of medicine required to treat an episode, but some United States residents purchased excessive amounts of antibiotics (e.g., four clients bought 100 pills, cough medicine (e.g., one client bought 200 pills), thyroid medication (e.g., two clients bought 250 pills), and contraceptives (e.g., four clients bought 10 months-worth). Antibiotics and analgesic opiates were among the products most frequently recommended (data not shown) by pharmacy clerks.

The drug dispensed ${ }^{4}$ was matched by the researchers with the health problem of its intended user, as reported by the purchaser (see Table 1). This information needs to be interpreted with caution since $41 \%$ of the products were purchased for a friend or relative by a purchaser who may not have had a

\footnotetext{
In this paper, the term "dispensation" is being used to mean "the handing over of the pre-packaged drug to the client." The authors are aware that dispensation frequently implies pharmaceutical care or could be understood in a legal sense according to the Supplement of the Mexican Pharmacopeia available at http://www.farmacopea.org.mx/ This was not the case in our sample of pharmacies.
} 
TABLE 3. Types of medicines purchased with or without a prescription in the pharmacies of Ciudad Juárez, Mexico, by country of residence of the intended recipient (end-user), AugustNovember 2007

\begin{tabular}{|c|c|c|c|c|c|c|}
\hline \multirow[b]{3}{*}{ Medications type } & \multirow{2}{*}{\multicolumn{2}{|c|}{ Total }} & \multicolumn{4}{|c|}{ End-user's country of residence } \\
\hline & & & \multicolumn{2}{|c|}{ Mexico } & \multicolumn{2}{|c|}{ United States } \\
\hline & No. & $\begin{array}{l}\% \text { with } \\
\text { prescription }\end{array}$ & No. & $\begin{array}{l}\% \text { with } \\
\text { prescription }\end{array}$ & No. & $\begin{array}{c}\% \text { with } \\
\text { prescription }\end{array}$ \\
\hline Analgesics & 49 & 35 & 31 & 32 & 18 & 39 \\
\hline Analgesic opiates & 9 & 0 & 3 & 0 & 6 & 0 \\
\hline Antibiotics & 54 & 35 & 22 & 50 & 32 & 25 \\
\hline Antifungal/antiviral/antiparasitics & 18 & 44 & 9 & 78 & 9 & 11 \\
\hline Fixed combinations & 29 & 59 & 22 & 50 & 7 & 86 \\
\hline Blood pressure medication & 26 & 19 & 7 & 43 & 19 & 11 \\
\hline Oral antidiabetics & 9 & 78 & 4 & 50 & 5 & 100 \\
\hline $\begin{array}{l}\text { Proton pump inhibitors/antiacids/ } \\
\text { histamine H2-receptor antagonists }\end{array}$ & 15 & 47 & 9 & 44 & 6 & 50 \\
\hline Antidiarrheals & 7 & 57 & 5 & 40 & 2 & 100 \\
\hline Antihistaminic & 7 & 43 & 6 & 50 & 1 & 0 \\
\hline Cough medicine & 11 & 18 & 7 & 29 & 4 & 0 \\
\hline Anticoagulants + antiplatelet drugs & 2 & 100 & 1 & 100 & 1 & 100 \\
\hline Contraceptives & 8 & 0 & 1 & 0 & 7 & 0 \\
\hline Bronchodilators & 4 & 50 & 1 & 100 & 3 & 33 \\
\hline Antiepileptic/antidepressants/anxiolytics & 6 & 67 & 4 & 75 & 2 & 50 \\
\hline Osteoporosis treatment & 2 & 50 & - & - & 2 & 50 \\
\hline Thyroid medicine & 6 & 17 & 1 & 100 & 5 & 0 \\
\hline Cholesterol lowering medication & 3 & 67 & - & - & 3 & 67 \\
\hline Vitamins/minerals/other nutrients & 13 & 46 & 8 & 50 & 5 & 40 \\
\hline Testosterone & 1 & 0 & - & - & 1 & 0 \\
\hline Corticosteroids & 7 & 29 & 2 & 50 & 5 & 20 \\
\hline Other OTC medicines ${ }^{a}$ & 25 & 40 & 14 & 57 & 11 & 18 \\
\hline Total (all types) & 311 & 38 & 157 & 47 & 154 & 29 \\
\hline
\end{tabular}

a Over the counter medication, available in the United States without a prescription.

full understanding of the symptoms; nevertheless some of the findings are revealing. For instance, multivitamins were bought for six persons who were feeling tired, four who had lost weight, and three who were tired and had lost weight; thyroid medicine, for three who had gained weight; cough medicine, for eight with productive coughs; and antibiotics, for 15 of 19 individuals who may have had upper respiratory infections.

\section{Characteristics of pharmacy clerks}

Given that in this study most products $(62 \%)$ were dispensed without a prescription, it was important to understand if the person dispensing the medication had the pharmaceutical knowledge and expertise necessary to promote its appropriate use. The interviews with the 9 traditional pharmacy owners and the highest ranking pharmacy clerk at 16 chain pharmacies indicated that clerks were young, had low levels of educa- tion, and the majority (91\%) had learned how to dispense medicine from their colleagues who themselves had not received formal training (Table 4).

Clerks at traditional pharmacies had more years of experience, in part because some of these pharmacies had been family-owned for many years and employees were related by kinship or friendship. Despite low levels of training, all clerks, except those in three traditional pharmacies, wore white coats, giving them the appearance of being professionals; $60 \%$ felt that they were well- or very well-qualified to advise clients on medications. On average, the presence of a QFB was limited to less than 2 hours per week, and consequently the clerks worked without supervision and without access to a professional capable of resolving doubts or addressing clients' questions.

Table 4 also shows that $32 \%$ of the pharmacies were routinely visited by 7-10 drug retailers per week; $84 \%$ of the respondents felt that the informa- tion provided by retailers is useful, and almost three-fourths trust them. Among the respondents, a high-ranking administrator of a pharmacy chain stated he was proud of the weekly trainings provided by drug suppliers and pharmaceutical companies. In addition, the study uncovered that pharmaceutical companies were offering financial incentives to promote their products, and those incentives were often extended to pharmacy clerks. The final income of some clerks, especially those working for pharmacy chains, was based on the amounts and types of products they were able to sell.

\section{Clerks' recommendations to clients}

Table 5 shows that when clients without a prescription requested a specific drug, only $37 \%$ of the clerks inquired about the nature of the health problem. When clients had a prescription, clerks offered an alternative product in $23 \%$ of the cases and one-third accepted the 
TABLE 4. Characteristics of Ciudad Juárez pharmacies and clerks, and opinions of clerks by type of pharmacy (chain or traditional/independentlyowned), August 2007-January 2008

\begin{tabular}{|c|c|c|c|c|c|c|}
\hline \multirow[b]{3}{*}{ Characteristic } & \multirow{2}{*}{\multicolumn{2}{|c|}{ Total }} & \multicolumn{4}{|c|}{ Pharmacy type } \\
\hline & & & \multicolumn{2}{|l|}{ Chain } & \multicolumn{2}{|l|}{ Traditional } \\
\hline & No. & $\%$ & No. & $\%$ & No. & $\%$ \\
\hline \multicolumn{7}{|l|}{ Pharmacies } \\
\hline Average hours per week with pharmacist present (range) & 1.4 hours $(1-4)$ & & 1.4 hours $(1-2)$ & & 1.5 hours $(1-4)$ & \\
\hline Average number of pharmacy clerks (range) & $5(1-13)$ & & $5(2-10)$ & & $4(1-13)$ & \\
\hline All employees wear a white coat & 25 & 88 & 16 & 100 & 9 & 67 \\
\hline \multicolumn{7}{|l|}{ Pharmacy clerks } \\
\hline Total number of clerks & 113 & & 78 & & 35 & \\
\hline \multicolumn{7}{|l|}{ Gender } \\
\hline Males & 55 & 49 & 34 & 44 & 21 & 60 \\
\hline Females & 58 & 51 & 44 & 56 & 14 & 40 \\
\hline \multicolumn{7}{|l|}{ Educational attainment } \\
\hline Primary school only & 8 & 7 & 3 & 4 & 5 & 14 \\
\hline Secondary school & 93 & 82 & 66 & 85 & 27 & 77 \\
\hline Technical/university training & 12 & 11 & 9 & 12 & 3 & 9 \\
\hline \multicolumn{7}{|l|}{ Learned to manage medicines through: } \\
\hline Practice & 103 & 91 & 76 & 97 & 27 & 77 \\
\hline Courses & 8 & 7 & - & - & 8 & 23 \\
\hline University degree & 2 & 2 & 2 & 3 & - & - \\
\hline Ability to communicate in English & 50 & 44 & 32 & 41 & 18 & 51 \\
\hline Average pharmacy experience (range) & 8.5 years $(<1-57)$ & & 6.9 years $(1-43)$ & & 12 years $(<1-57)$ & \\
\hline Average age & 34.4 years & & 32.7 years & & 38.1 years & \\
\hline \multicolumn{7}{|l|}{ Opinions of pharmacy clerks } \\
\hline Total number of respondents & 25 & & 16 & & 9 & \\
\hline \multicolumn{7}{|l|}{ How could you better respond to your clients? ${ }^{a}$} \\
\hline More frequent and periodic training & 12 & 48 & 9 & 56 & 3 & 33 \\
\hline Training on how to serve the client & 7 & 28 & 6 & 38 & 1 & 11 \\
\hline A better facility & 9 & 36 & 6 & 38 & 3 & 33 \\
\hline Better inventory and better prices & 3 & 12 & - & - & 3 & 33 \\
\hline Everything is fine & 4 & 16 & 3 & 3 & 1 & 11 \\
\hline \multicolumn{7}{|l|}{ How often are you visited by pharmaceutical retailers? } \\
\hline$<1$ per week & 7 & 28 & 2 & 13 & 5 & 55 \\
\hline 1-3 per week & 10 & 40 & 7 & 44 & 3 & 33 \\
\hline 7-10 per week & 8 & 32 & 7 & 44 & 1 & 11 \\
\hline Information of drug representatives is useful & 21 & 84 & 14 & 88 & 7 & 78 \\
\hline Information provided by drug representatives is trustworthy & 18 & 72 & 13 & 81 & 5 & 56 \\
\hline
\end{tabular}

a Open-ended questions with a maximum of three responses.

recommendation. Overall, the clerk's recommendation was accepted in $69 \%$ of the cases.

Ninety percent of clients who bought any type of medicine without a prescription asked for the product by name, and none of the clerks referred the client to a physician or expressed concern about selling the product without a prescription. Of 19 clients who went to the pharmacy seeking advice, all received a recommendation from the clerk and all but one bought the recommended drug. Only one client was referred to a physician.

Of all the products dispensed, 13\% were accompanied by verbal information only. The clerks provided very little information about adverse events; drug interactions were not discussed during any of the observed clerk-client interactions.

\section{DISCUSSION}

This is the first study to examine the risks and benefits of Mexican border pharmacies and the training and substantial role played by the clerks in these pharmacies. This study has shown that the use of Ciudad Juárez pharmacies entails risks, can be a waste of resources, and might lead to overmedication. Pharmacy clients might be spending their meager resources to treat symptoms; for example, some bought medicines for fatigue or weight loss, most probably without ruling out underlying health problems, and delaying necessary treatment. Patients also purchased medicines that could hinder recovery (e.g., cough medicine when having productive cough), medicines that when used inappropriately could be detrimental to their health (e.g., thyroid medicine and some irrational fixed-dose combinations), or that of the community at large (e.g., antibiotics).

The availability of walk-in clinicswhere physicians diagnose and prescribe for a minimal fee-is very attractive to patients, including United States residents who are either uninsured, cannot access medical care in a timely manner, or cannot afford co-payments. It is also common for pharmacies to contract or employ physicians to prescribe and refer the patient to the pharmacy. In some instances, the physician's compensation is based on the number of prescriptions, a situation that creates a conflict of interest and might lead to the prescription of unneeded medicines (24).

The Mexican government's decision (August 2010) to enforce the legislation requiring a prescription to purchase antibiotics may have decreased the number of OTC sales of antibiotics. However, 
TABLE 5. Information provided by pharmacy clerks in Ciudad Juárez while dispensing medicines to clients, August 2007-January 2008

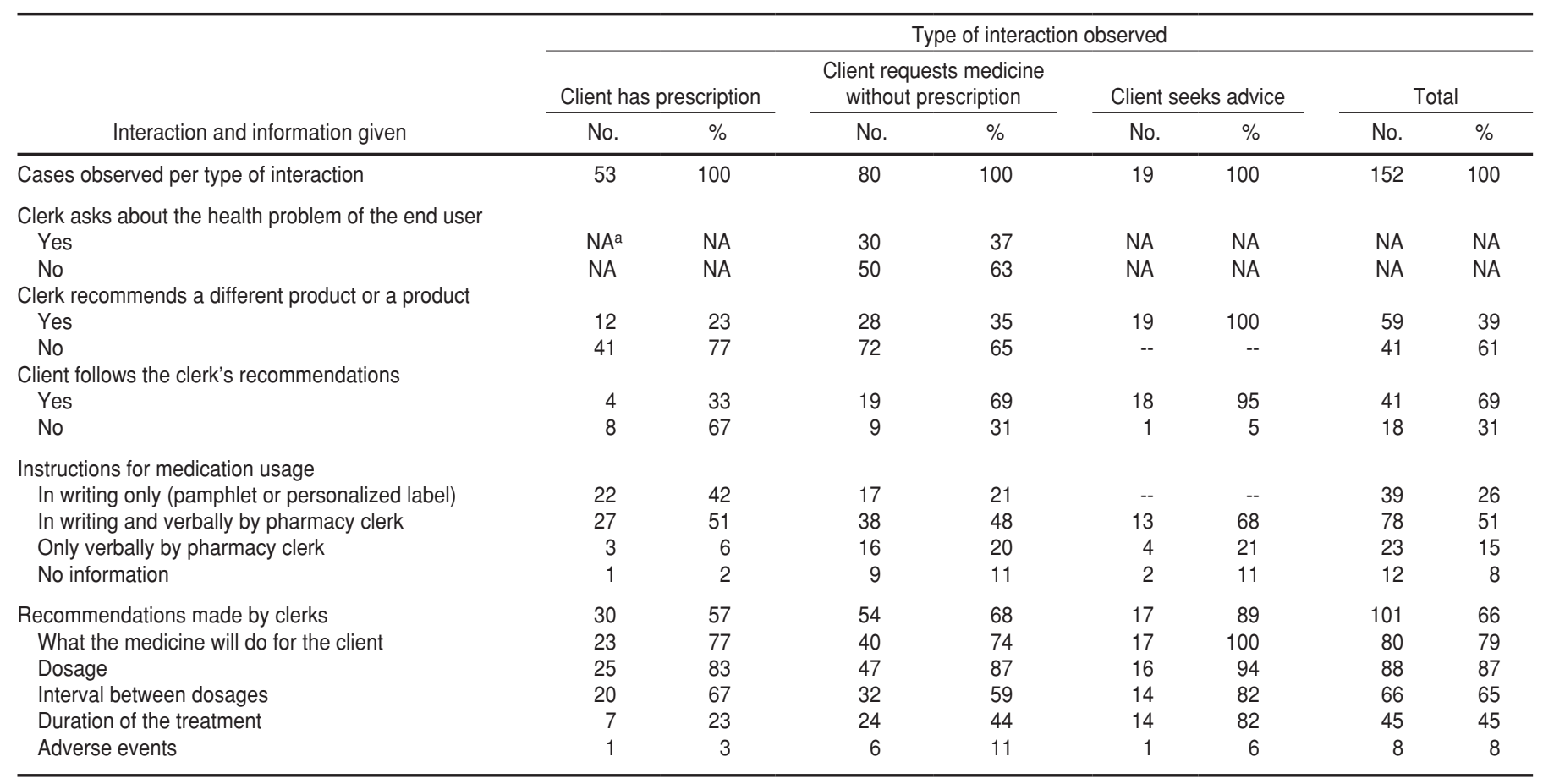

a $\mathrm{NA}=$ not applicable.

researchers at the Instituto Nacional de Salud Pública (National Institute of Public Health, Cuernavaca, Mexico) have pointed out that this led to an increase in the number of consultation rooms near pharmacies (personal communication, 16 April 2011). Now, patients have to visit a physician, but little was done to limit over-prescription by medical/ dental professionals and to encourage the appropriate use of antibiotics.

The potentially biased information offered by the drug industry and distributors and compensating pharmacy clerks based on sales also may cause overmedication. The sale of unneeded medicines coupled with the absence of pharmacists, the presence of untrained clerks, the observed tendency of Mexican physicians to write few instructions in their prescriptions, and the limited information contained in the package inserts of prescription-only medicines, translate into clients having access to medications, but receiving very little or incorrect information on how to use them.

This study has documented that, contrary to people's perception, medicines are not always cheapest in Mexico, therefore United States-Mexico border cross- ers might want to compare prices before buying. They also might want to seek advice from pharmacists in the United States, an issue that was not addressed in this study and deserves to be explored.

\section{Study limitations}

The study limitations are the use of a convenience sample, the fact that two pharmacy chains refused to participate, and its relatively small sample size. While the findings cannot be extrapolated to all Mexican pharmacies, the study has unveiled regulatory voids and pervasive organizational practices that are not exclusive to the pharmacies studied, ones that impact the type of products purchased and how medication is used. Additionally, the observers of client-clerk interactions could not always capture the name of the product under discussion, which limited analysis of the dispensation process.

\section{Conclusions}

It is important to acknowledge that if United States border residents were unable to use Mexican providers and pharmacies, the unmet need for services would double, and a relatively high percentage of poor, chronically ill patients $(35 \%)$ would not be able to follow their treatment (21). As long as there is no universal access to medical care, United States border residents will continue to use Mexican pharmacies as their last resort.

We would like to suggest some measures that could reduce the risks and improve the use of pharmaceuticals in the border area.

1. It would be advisable to limit the conflicts of interest built into financial compensation offered to pharmacy clerks and physicians working in close collaboration with pharmacy chains. These financial incentives lead physicians to over-prescribe and pharmacy clerks to increase the sale of selected products, and do not contribute to promoting the appropriate use of pharmaceuticals.

2. Pharmacies could distribute informational leaflets with all pharmaceutical products, but especially in prescription-only products that are currently sold with very limited accompanying information. These leaflets should be designed by communi- 
cation specialists and the information should be provided by experts not under the payroll of the pharmaceutical industry.

3. United States clinics and others serving the poor and uninsured might remind those in need about the availability of some low-priced, generic medicines in United States pharmacies.

4. Given the dearth of QFBs trained in community pharmacy (25), consideration should be given to the development of a technical degree, such as the pharmacy technician degree implemented in Cuba (26).

5. Given the importance of Mexican pharmacies for United States resi- dents, the United States border leaders may consider collaborating with Mexican health authorities in the development of joint programs to promote the adequate use of pharmaceuticals, including antibiotics; in training pharmacy technicians; and in the development of educational materials to be distributed in pharmacies.

Finally, policymakers and professional associations may need to take decisive steps denouncing practices that put the health of pharmacy clients at risk. Successful implementation of these solutions will require a concerted effort by stakeholders, i.e., regulators, prescribers, in- dustry, distributors, pharmacy owners, clerks, the community, and consumers.

Acknowledgements. The authors would like to thank Anahí Dreser, René Leyva Flores, and Veronika J. Wirtz from the Instituto Nacional de Salud Pública of Mexico for the support given throughout the project and the many useful comments provided during the preparation of this article.

Funding. This study was made possible by a grant from El Paso del Norte Health Foundation (El Paso, Texas, United States).

Conflicts of interest. None.

\section{REFERENCES}

1. Gross DJ. The consumer and reimportation. Managed Care. 2004;13:43-4.

2. Boshle MJ, Balkrishan R. Drug reimportation practices in the United States. Ther Clin Risk Manag. 2007;3(1):41-6.

3. House of Representatives Bill: Pharmaceutical Market Access and Drug Safety Act of 2007. Available from http://www.govtrack. us/congress/bills/110/hr380 Accessed on 14 January 2013.

4. Nolen LA, Ball R, Piñon M, Shepherd MP. Using medications purchased in Mexico: position statement of the Texas Society of Health-Systems Pharmacists. Am J Health Syst Pharm. 2002;59:1289-90.

5. Shepherd MD. Drug quality, safety issues and threats to drug importation. Available from http://heinonline.org/HOL/LandingPage? collection $=$ journals\&handle $=$ hein.journals $/$ calwi36\&div $=13 \&$ id $=\&$ page $=$ Accessed on 13 March 2013.

6. Shepherd MD. Impact of drug importation on community pharmacy and patient care. J Am Pharm Assoc. 2007;47(3):319-27.

7. United States Food and Drug Administration. FDA warns consumers about counterfeit drugs purchased in Mexico. Silver Spring, MD: FDA; 30 July 2004. (FDA Talk Paper T04-28).

8. United States Food and Drug Administration. FDA warns consumers about counterfeit drugs purchased in Mexico. Silver Spring, MD: FDA; 5 May 2005. (FDA Talk T05-20).

9. Karlage KL, Myrdal PB. Comparison of three pharmaceutical products obtained from Mexico and the United States: a case study. Drug Dev Ind Pharm. 2005;31(10):993-1000.

10. Schwertner AH, Storrow BA. Comparison of actual and stated concentration of pharmaceuticals manufactured in Mexico. ClinTher. 2005;27(5):609-15.
11. Institute of Policy and Economic Development, The University of Texas at El Paso. At the cross roads: US/Mexico border counties in transition. El Paso, Texas: UTEP; 2006.

12. Families USA Foundation. Crossing to Mexico: priced out of American health care. Washington DC: Families USA Foundation; 1992.

13. Landeck M, Garza C. Utilization of physician health care services in Mexico by US Hispanic border residents. Health Mark Q. 2003;20(1):3-16.

14. Ortiz L, Arizmendi L, Cornelius LJ. Access to health care among Latinos of Mexican descent in colonias in two Texas counties. J Rural Health. 2004;20(3):246-52.

15. Escobedo L, Cardenas VM. Utilization and purchase of medical care services in Mexico by residents in the United States of America 1998-1999. Rev Panam Salud Publica. 2006;19(5):300-5.

16. Byrd TL, Law JG. Cross-border utilization of health care services by United States residents living near the Mexican border. Rev Panam Salud Publica. 2009;26(2):95-100.

17. Casner PR, Guerra LG. Purchasing prescription medication in Mexico without a prescription. The experience at the border. Western J Medicine. 1992;156 (5):512-6.

18. Texas Department of State Health Services' Office of Border Health. 2007 Health Risk Factors Report. Available from: http://www. dshs.state.tx.us/borderhealth/ Accessed on 8 January 2013.

19. Rivera JO, Ortiz M, Cardenas V. Cross-border purchase of medications and health care in a sample of residents of El Paso, Texas, and Ciudad Juarez, Mexico. J Natl Med Assoc. 2009;101(2):167-73.

20. Bastida E, Brown SH, Pagán JA. Persistent disparities in the use of health care along the
US-Mexico border: an ecological perspective. Am J Public Health. 2008;28(11):1987-95.

21. Homedes N. The health seeking behavior of undocumented immigrants in El Paso County. El Paso, Texas: Center for Border Health; 2008. Pp. 145.

22. Wirtz VJ, Leyva Flores R, Dresser A, Corbett KK. Organización y funcionamiento de las farmacias en México. In: Homedes N, Ugalde A, eds. Las farmacias, los farmacéuticos y el uso adecuado de medicamentos en América Latina. Buenos Aires: Editorial Lugar; 2011. Pp. 59-82.

23. Dresser A, Wirtz VJ, Leyva Flores R. Las farmacias mexicanas: regulación y políticas. In: Homedes N, Ugalde A, eds. Las farmacias, los farmacéuticos y el uso adecuado de medicamentos en América Latina. Buenos Aires: Editorial Lugar; 2011. Pp. 27-57.

24. Quiroz T. México: El funcionamiento de algunas farmacias. Available from: http:// www.saludyfarmacos.org/boletin-farmacos/ boletines/feb2011/Mexico-funcionamientode-algunas-farmacias/ Accessed on 24 September 2011.

25. World Health Organization. World health statistics. Available from: http://www.who. int/whosis/whostat/EN_WHS2011_Full.pdf Accessed on 24 September 2011.

26. Debesa García F, Arbesú Michelena MA, Pérez Peña JL. Los servicios farmacéuticos en Cuba. Situación actual, retos y perspectivas. In: Homedes N, Ugalde A, eds. Las farmacias, los farmacéuticos y el uso adecuado de medicamentos en América Latina. Buenos Aires: Editorial Lugar; 2011. Pp. 209-26.

Manuscript received on 17 February 2012. Revised version accepted for publication on 29 November 2012. 
RESUMEN Objetivo. Determinar los beneficios y riesgos que supone acudir a farmacias mexicanas mediante una mejor comprensión de los datos sociodemográficos de los clientes de las farmacias de Ciudad Juárez y sus necesidades de medicamentos; y evaluar la

Farmacias mexicanas: beneficios y riesgos para los residentes de la frontera entre Estados Unidos de América y México

función y pericia de los auxiliares administrativos de farmacia y su repercusión sobre el uso de los medicamentos.

Métodos. Se realizó un estudio transversal de una muestra de conveniencia de 32 farmacias de Ciudad Juárez entre agosto del 2007 y enero del 2008. Los profesionales médicos entrevistaron a 230 clientes y 25 propietarios y auxiliares administrativos de las farmacias, y observaron 152 interacciones entre los auxiliares administrativos y los clientes. Se compararon los precios de los medicamentos adquiridos con mayor frecuencia con los de las farmacias de El Paso, Texas, Estados Unidos.

Resultados. De los 311 medicamentos adquiridos, los más frecuentes fueron antibióticos (54), analgésicos (49), asociaciones de medicamentos a dosis fijas (29) y antihipertensivos (26). Solo $38 \%$ de los medicamentos se compraron con receta; $62 \%$ de los medicamentos de venta con receta que se adquirieron sin ella eran automedicados. Muchos de los productos comprados tenían un valor terapéutico limitado y otros podían ser nocivos si se utilizaban de forma inadecuada. Los auxiliares administrativos de farmacia estaban mal capacitados y no ofrecían información adecuada sobre el consumo de medicamentos; nunca abordaban las contraindicaciones. Contrariamente a la percepción popular, algunos medicamentos genéricos resultaron ser más baratos en los Estados Unidos que en México. Se identificaron conflictos de intereses que podrían estar dando lugar a la sobremedicación.

Conclusiones. Aunque los riesgos son evidentes, algunos residentes de los Estados Unidos que padecen enfermedades crónicas y carecen de seguro médico pueden beneficiarse del acceso a medicamentos prescritos previamente por un médico, sin obtener una receta nueva. Los autores proponen cinco pasos para reducir los riesgos y mejorar la utilización de las farmacias en la zona fronteriza.

Palabras clave Servicios comunitarios de farmacia; educación en farmacia; medicamentos bajo prescripción; áreas fronterizas; México; Estados Unidos. 